\title{
QUALITY OF BEDROCK GROUNDWATER IN WESTERN FINLAND, WITH SPECIAL REFERENCE TO NITROGEN COMPOUNDS
}

\author{
ENN KARRO
}

KARRO, ENN 1999. Quality of bedrock groundwater in western Finland, with special reference to nitrogen compounds. Bulletin of the Geological Society of Finland 71, Part 2, 243-251.

Monitoring of bedrock aquifers utilized for water supply in the Vaasa region, western Finland, suggests slight changes in the chemical composition of groundwater resulting both from natural and anthropogenic factors. Applying the permissible limits for parameters in drinking water reveals that the groundwater quality is generally good. Groundwater occurring in fractures and fissures of the crystalline bedrock is protected from anthropogenic pollution by clay and till deposits with low permeability. Temporally, the contents of nitrogen compounds in groundwater exhibit a decreasing trend. Reducing conditions prevailing in bedrock aquifers are reflected in elevated ammonium, iron and manganese contents in water.

Key words: water supply, ground water, aquifers, bedrock, drilled wells, water quality, hydrochemistry, nitrogen, pollution, atmospheric precipitation, Ostrobothnia, South Ostrobothnia, Finland

Enn Karro: Department of Geology, P.O. Box 11, FIN-00014 University of Helsinki, Finland and Institute of Geology, University of Tartu, Vanemuise 46, 51014 Tartu, Estonia

\section{INTRODUCTION}

In the present study the occurrence of nitrogen compounds in bedrock groundwater is briefly discussed on the basis of hydrochemical data collected from the Vaasa region (Fig. 1). The paper describes the results of the investigation of the bedrock groundwater at shallow and medium depths, i.e. the local flow zone, which according to Salmi (1985) extends to a depth of about $200 \mathrm{~m}$ in Finland. The results of analyses of water samples from 23 drilled wells (from 19 locations, Fig. 1) were extracted from the database compiled by the
West Finland Regional Environment Center. Data interpreted here show a large spread in terms of sampling intervals and sampling frequencies. At some waterworks the water quality has been monitored during the last 20-30 years (6-10 analyses), but from others only 1-3 analyses are available. The depth of the wells ranges from 20 to 150 meters and the amount of abstracted groundwater is generally some tens of $\mathrm{m}^{3} / \mathrm{d}$. Groundwater chemistry is compared to the quality standards set by the Ministry of Social Affairs and Health (Anonymous 1994). 


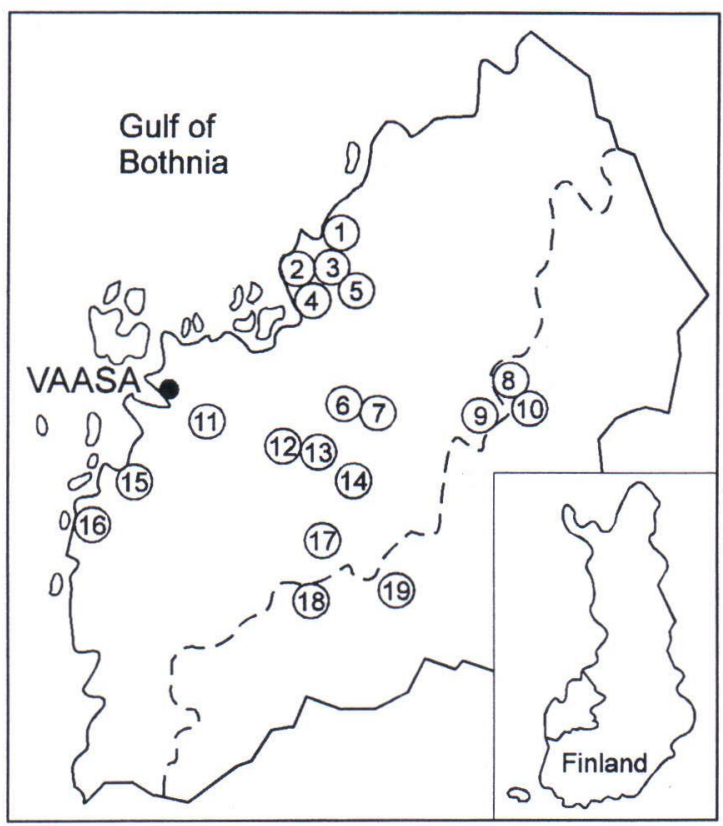

Fig. 1. Schematic map of Western Finland showing the location of the studied bedrock aquifers: 1-Stranden, 2Monäs, 3-Munsala Källan, 4-Hirvlax, 5-Silvast, 6-Kosola, 7-Rintakangas, 8-Lappajärvi, 9-Ylipää, 10-Pokela, 11-Ruto, 12-Isokyrö, 13-Lavo, 14-Munkkila, 15Norrby and Petalax, 16-Harrström, 17-Ryöskölä, 18Luopa, 19-Peräseinäjoki. Dotted line marks the highest limit of the postglacial Litorina Sea.

\section{GENERAL GEOLOGICAL SETTING OF AREA}

The bedrock of the Vaasa region is composed of folded and metamorphosed Svecofennidic mica schists, phyllites and mica gneisses intruded by granitoids (Simonen 1980). The principal system of faults and fractures in the crystalline bedrock was already established in the course of extensive tectonic activity before the Middle Proterozoic (Niini 1987). The ancient structural pattern of the bedrock underwent some modifications during the Quaternary glaciations (Talvitie 1979). Because of the glacial abrasion the topography of the area is relatively smooth and the weathering zone between the soil and the bedrock is practically absent. The relief varies between 0 and $200 \mathrm{~m}$ a.s.1. In topographical heights the bedrock is exposed or commonly overlain by a few meters of soil. Topographical depressions form valleys in which the soil cover is thicker. The most widely distributed soil type is till, which overlies the bedrock as a thin, discontinuous layer. Other commonly found sediments are glaciofluvial sands and gravels, as well as marine and lacustrine clays and silts, sometimes measuring up to tens of meters in thickness. As these deposits usually occupy topographic depressions they have frequently been subject to paludification and are overlain by peat.

The evolution of groundwater conditions over the entire region has been controlled by recurring continental glaciations in the course of the Pleistocene. The evolutionary stages of the Baltic Sea with their different extents and the salinity of inundating waters have influenced the development of the chemical composition of groundwater. The present chemical character of shallow groundwater is a result of the infiltration of fresh atmospheric water modified by bedrock/soil and groundwater interaction.

\section{GROUNDWATER QUALITY AND THE DISTRIBUTION OF NITROGEN COMPOUNDS IN GROUNDWATER}

When studying the bedrock groundwater of the Vaasa region from the point of view of quality requirements, it can be stated that these are generally fulfilled. The limits for $\mathrm{NO}_{2}(0.01 \mathrm{mg} / \mathrm{l})$ and $\mathrm{NO}_{3}(25 \mathrm{mg} / \mathrm{l})$ in groundwater are exceeded only in a few cases. Ammonium contents above the limit of $0.5 \mathrm{mg} / 1$ are recorded more frequently, suggesting reduced conditions prevailing in some aquifers. The groundwater is also characterized by high $\mathrm{Fe}$ and $\mathrm{Mn}$ content and high $\mathrm{KMnO}_{4}$ consumption value. As extensive areas of the Vaasa region were inundated by waters of the Litorina Sea, chloride concentrations higher than $100 \mathrm{mg} / \mathrm{l}$ have been detected in four monitored wells (Isokyrö, Ruto, Hirvlax and Monäs). Selected parameters of groundwater analyses are summarized in Table 1.

Mean concentrations of nitrogen compounds of the Vaasa region (columns 1) and the analytical 
Table 1. Selected hydrochemical properties of bedrock groundwater in the Vaasa region compared to the limit values set by standard.

\begin{tabular}{|c|c|c|c|c|c|c|c|c|c|c|}
\hline & $\mathrm{pH}$ & $\begin{array}{c}\mathrm{EC} \\
\mathrm{mS} / \mathrm{m}\end{array}$ & $\begin{array}{c}\mathrm{KMnO}_{4} \\
\mathrm{mg} / \mathrm{l}\end{array}$ & $\begin{array}{l}\mathrm{NH}_{4} \\
\mathrm{mg} / 1\end{array}$ & $\begin{array}{l}\mathrm{NO}_{2} \\
\mathrm{mg} / \mathrm{l}\end{array}$ & $\begin{array}{l}\mathrm{NO}_{3} \\
\mathrm{mg} / 1 \\
\end{array}$ & $\begin{array}{c}\mathrm{Fe} \\
\mathrm{mg} / \mathrm{l}\end{array}$ & $\begin{array}{l}\mathrm{Mn} \\
\mathrm{mg} / \mathrm{l}\end{array}$ & $\underset{\mathrm{mg} / \mathrm{l}}{\mathrm{F}}$ & $\begin{array}{c}\mathrm{Cl} \\
\mathrm{mg} / \mathrm{l}\end{array}$ \\
\hline Mean & 6.8 & 41 & 16 & 0.25 & 0.03 & 2.2 & 2.97 & 0.35 & 0.5 & 45 \\
\hline Median & 6.8 & 29 & 12 & 0.10 & 0.01 & 0.8 & 1.34 & 0.20 & 0.3 & 22 \\
\hline Maximum & 8.5 & 121 & 53 & 2.10 & 0.50 & 58.0 & 15.00 & 2.00 & 1.7 & 260 \\
\hline Minimum & 5.5 & 4 & 1 & 0.01 & 0.00 & 0.0 & 0.00 & 0.00 & 0.1 & 0 \\
\hline $\mathrm{n}$ & 89 & 83 & 75 & 88 & 86 & 89 & 89 & 79 & 43 & 79 \\
\hline Limit value* & $7.0-8.8$ & $<40$ & $<12$ & 0.50 & 0.10 & 25.0 & 0.20 & 0.05 & 1.5 & 100 \\
\hline
\end{tabular}

* Groundwater quality standards set by the Ministry of Social Affairs and Health (Anonymous 1994).

$\mathrm{EC}=$ electrical conductivity, $\mathrm{KMnO}_{4}=\mathrm{KMnO}_{4}$ consumption

results obtained in some earlier investigations (columns 2-8) are schematically presented in Fig. 2. A comparison of the values plotted in the diagram shows that the mean contents of nitrogen compounds in bedrock groundwater are on the same order of magnitude in both the present and earlier studies (Laakso 1966, Rönkä 1983, Hyyppä 1984, Lahermo et al. 1990, Korkka-Niemi et al. 1993). The abundance of $\mathrm{NO}_{2}$ in groundwater is exactly the same $(0.03 \mathrm{mg} / \mathrm{l})$ in most of the compared results, except for the Laakso's (1966) mean of the whole country (columns 3 ). Thus, regionally there appear to be no differences between the concentrations of $\mathrm{NO}_{2}$ in bedrock groundwater. Its low concentration indicates that nitrite is unstable and tends to oxidize to nitrate or to reduce to ammonium quite quickly.

Mean $\mathrm{NO}_{3}$ values in bedrock groundwater in Finland as a whole have increased from 1960s to 1990s (Laakso 1966, Lahermo et al. 1990). However, according to the results by Korkka-Niemi et al. (1993), no increase in nitrogen compounds in bedrock groundwater was observed. The data available from the Vaasa area show the lowest mean $\mathrm{NO}_{3}$ concentration compared to the results of earlier studies. The median values of $\mathrm{NO}_{3}$ in the Vaasa aquifers and in the bedrock wells covered by the nation-wide water survey are approximately the same, 0.8 and $1.0 \mathrm{mg} / \mathrm{l}$, respectively (Korkka-Niemi et al. 1993). The corresponding value in bedrock wells is much higher $(2.4 \mathrm{mg} / \mathrm{l})$ according to the results of hydrochemical mapping

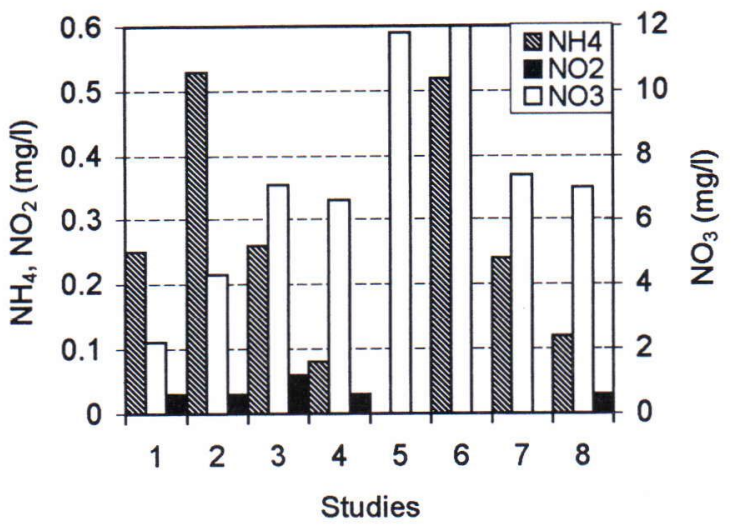

Fig. 2. Concentrations of nitrogen compounds in bedrock groundwater. 1 - Vaasa region (present study); 2 - former Vaasa county (Laakso 1966); 3 - Finland as a whole (Laakso 1966); 4 - Middle Finland, Savo, Vehmaa and Helsinki district (Rönkä 1983); 5 - Finland as a whole (Lahermo et al. 1990); 6 - Finland as a whole, < $100 \mathrm{~m}$ deep drilled wells (Hyyppä 1984); 7 Finland as a whole, > 100 m deep drilled wells (Hyyppä 1984); 8 - Finland as a whole (Korkka-Niemi et al. 1993). Columns represent the mean values of the concentrations.

carried out by the Geological Survey of Finland (Lahermo et al. 1990).

Hyyppä (1984) calculated the mean and median chemical composition of groundwater samples from $<100 \mathrm{~m}$ and $>100 \mathrm{~m}$ deep drilled wells. A remarkable depletion in the content of nitrogen compounds in bedrock groundwater with increasing depth can be observed (Fig. 2, columns 6 and 
7). The median values of $\mathrm{NH}_{4}$ and $\mathrm{NO}_{3}$ content in the $>100 \mathrm{~m}$ deep wells $(0.10$ and $1.0 \mathrm{mg} / 1$, respectively) are close to those detected in present study (Table 1). However, there is no obvious relationship between the concentration of nitrogen compounds and well depth in the Vaasa region.

Relative concentrations of ammonium and nitrate depend on the degree of nitrification. The $\mathrm{NO}_{3} / \mathrm{NH}_{4}$ ratio in the bedrock groundwater of the Vaasa area (8.8) is considerably lower compared to that in the Finnish bedrock groundwater as a whole. Based on the results of investigations referred to above, the $\mathrm{NO}_{3} / \mathrm{NH}_{4}$ ratio in the Finnish bedrock groundwater varies from 25 to 58 . The results of the present study as well as Laakso's (1966) data from the Vaasa region, refer to reducing conditions prevailing in the bedrock groundwater of this area. The nitrogen compounds in water tend to occur in the most reduced states.

\section{POTENTIAL SOURCES OF NITROGEN COMPOUNDS}

The natural geochemistry of bedrock groundwater is closely related to the geology of its host rock. The amount of nitrogen compounds in the bedrock itself is practically nil. According to Taylor (1964), the mean nitrogen content of igneous rocks is $20 \mathrm{ppm}$ or $0.002 \%$ by weight. This nitrogen appears to be in chemical combination, mainly as ammonium nitrogen. The possible substitution of $\mathrm{K}^{+}$(ionic radii $133 \mathrm{pm}$ ) by $\mathrm{NH}_{4}{ }^{+}(143 \mathrm{pm}$ ) might offer a possibility of explaining the manner of occurrence of nitrogen in rocks. Stevenson (1962) has shown that nitrogen may exist as ammonium ions held in structures of micas and feldspars and only little, if any, of the nitrogen in igneous rocks is in organic combination. Oxidized nitrogen is absent in rocks and insignificant amounts of nitrogen compounds are liberated from rocks during weathering. Thus, their presence in groundwater results largely from the decomposition of organic matter in surficial deposits, atmospheric deposition and various anthropogenic sources.

Shallow hard rock systems are particularly susceptible to pollution from a variety of agricultural and industrial pollutants. The buffering capacity of hard rock groundwaters is generally poor and they are susceptible to acid inputs from acid deposition. Insufficient information is available, however, to understand the role of such rocks in buffering groundwater and attenuating pollution.

Groundwater pollution incidents can be divided into two broad types on the basis of the source and mode of propagation of pollutants. Pointsource pollution occurs where pollutants are derived from a discrete, often readily identifiable source such as a factory, farm, leaking tank or waste disposal site. Diffuse pollution occurs where pollutant input is widely distributed and cannot be pin-pointed precisely. Examples are the ammonium fertilizers used in agriculture and forestry and acid rain, which may be distributed on a regional or national scale.

Bedrock groundwater is in continuous motion and participates in the annual hydrologic cycle. Groundwater is most mobile in the surface parts of the Finnish bedrock and its movement slows down with increasing depth (Salmi 1985). In Norway, transmissive fractures in the upper $12 \mathrm{~m}$ of a granite led to hydraulic conductivities two orders of magnitude higher than the hydraulic conductivity in the background granite (Banks et al. 1992). According to Rönkä (1983), the best average yields $\left(46 \mathrm{~m}^{3} / \mathrm{d}\right)$ are given by drilled wells in the depth range of $41-50 \mathrm{~m}$. The fact that fresh groundwater is obtained almost invariably from drilled wells extending down to a depth of $200 \mathrm{~m}$ in Finland indicates that groundwater circulation may extend deep in the bedrock. Hyyppä (1984) has demonstrated that groundwater in fracture zones (drilled wells $>60 \mathrm{~m}$ deep) contains more nitrogen than that in areas of unbroken bedrock. Jacks (1973) has found the amount of total nitrogen to decrease in bedrock groundwater with increasing depth. In a study carried out by Pirhonen (1990) in the coastal areas of southern Finland an increase in $\mathrm{NH}_{4}$ concentration with depth in bedrock groundwater has been recorded.

In an area of exposed bedrock, the groundwater table corresponds to topography as does the groundwater table in the overburden, being somewhat deeper in uplands than in lowlands. In the 

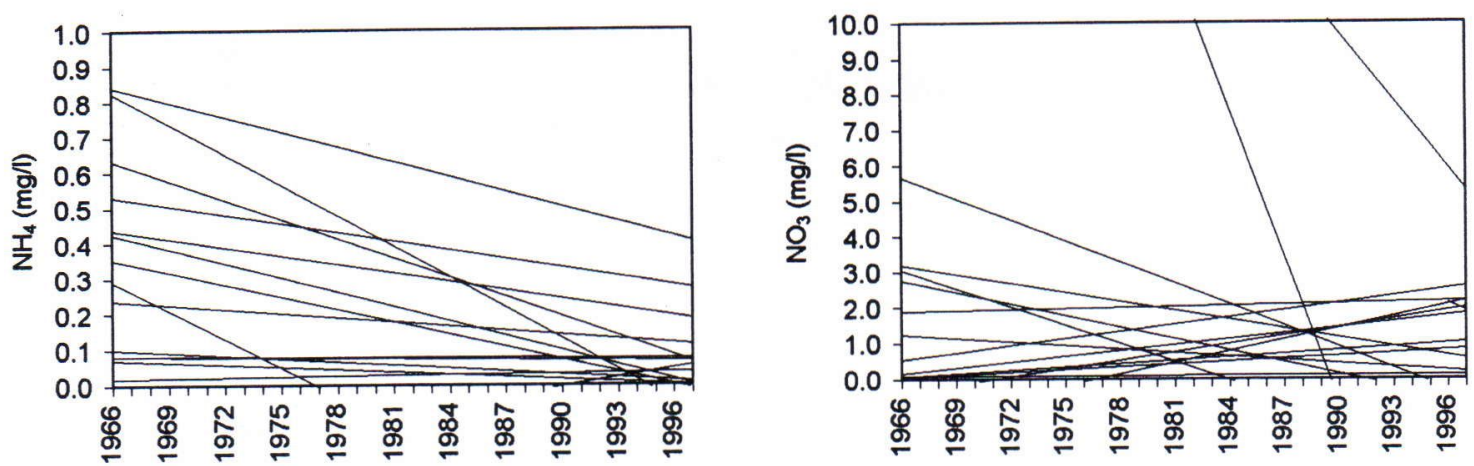

Fig. 3. Trendlines of data series representing the temporal increase or decrease of $\mathrm{NH}_{4}$ and $\mathrm{NO}_{3}$ concentration in bedrock groundwater.

Vaasa region groundwater levels are generally close to the ground surface. Thus the unsaturated zone provides little protection and pollutants will rapidly reach the water table. Infiltration from soil into bedrock occurs at specific sites where suitable combinations of geological and hydrological variables exist (Olofsson 1994), e.g. in cases where conductors in the bedrock, such as fractures and fracture zones, are hydraulically connected with a groundwater reservoir in permeable soil or with horizons of permeable and conductive material in heterogeneous soil. The hydraulic conditions of the contact zone between soil and rock are of particular importance for infiltration, even a thin layer of silt on the bedrock surface may block the water flow.

\section{Point-source pollution}

It is supposed that an increase in abundances of dissolved components, including nitrogen compounds, occurs in groundwater as a result of human activities. In the case of point-source pollution the changes in groundwater chemistry can be locally large, if the sediment is permeable. Due to the quite low concentration of nitrogen compounds, the presence of anthropogenic pollution may be clearly recognized only in a few of the studied areas. The changes in groundwater quality can be attributed to the point-source pollutants in the Norrby and Stranden waterworks (Fig. 1). Both wells are situated adjacent to farms (100$200 \mathrm{~m}$ ) and the fluctuating content of $\mathrm{NH}_{4}$ and
$\mathrm{NO}_{3}$ in the Norrby aquifer have exceeded the limit values set by the standard. Furthermore, the highest $\mathrm{NO}_{3}$ concentration $(58.0 \mathrm{mg} / \mathrm{l})$ has been detected in Norrby, too.

In spite of some elevated concentrations of $\mathrm{NH}_{4}$ and $\mathrm{NO}_{3}$ the general depletion of these ions in the Vaasa groundwater is commonplace. Trendlines of plotted $\mathrm{NH}_{4}$ and $\mathrm{NO}_{3}$ values show the general temporal changes in concentrations of these components in groundwater (Fig. 3). Most of the $\mathrm{NH}_{4}$ abundances in the monitored drilled wells exhibit a declining trend. In the case of very low $\mathrm{NH}_{4}$ concentrations the trendlines are approximately horizontal referring to natural conditions prevailing in the aquifers. On the $\mathrm{NO}_{3}$ plot both declining and slightly ascending trendlines are presented. The two deeply declining lines represent the decrease of $\mathrm{NO}_{3}$ abundances in the Norrby and Hirvlax groundwater. The decreasing trend may be partly explained by earlier agricultural activity, resulting in the accumulation of nitrogen compounds in the soil. When the pumping of groundwater basin progressed, the amount of dissolved matter, including nitrogen compounds, diminished with time (Fig. 3). As a consequence of acceleration of groundwater flow, pure groundwaters from more distal parts of aquifer are mixed with slightly polluted water. In the case that groundwater is pumped constantly, the quantity of dissolved matter attains the level characteristic of the groundwater basin in question. Variations in it, again, depend particularly on changes in the utilization of water, variations in the hydrometeorological 
factors and possible contamination of the recharge area of groundwater.

\section{Atmospheric deposition}

The studied waterworks are influenced by longterm effects from relatively low concentrations of atmospheric deposition. In rural areas the infiltration of precipitation might, besides decomposition of organic matter in surficial deposits, be the only source of nitrogen compounds in bedrock groundwater. Major nitrogen compounds present in the atmosphere are nitrogen oxides $\left(\mathrm{NO}_{x}\right)$ and ammonia $\left(\mathrm{NH}_{3}\right)$. Normally, most of the nitrogen compounds added to the soil via precipitation and dry deposition will be adsorbed and transformed in the humus-rich soil zone and taken up by vegetation. If nitrogen compounds are deposited via precipitation more than what the vegetation can utilize, then surplus will seep through the topsoil and overburden into the bedrock groundwater.

The effects of acid deposition on groundwater quality have been studied by Hrkal (1992) in the metamorphic rocks and granites of the Bohemian Massif. The extensive use of the poor quality fossil fuels has led to a five fold increase in the average concentration of $\mathrm{NO}_{3}$ (from $4 \mathrm{mg} / 1$ to $19 \mathrm{mg} / \mathrm{l}$ ) in groundwater over a 25 year period. Changes in Sweden and Finland appear to be less pronounced than those in Bohemia (Swedberg 1989, Knutsson 1994, Soveri 1992, Lahermo 1991, 1994, RuohoAirola et al. 1998). Nitrates occur in rainwater in concentrations of $0.3-0.5 \mathrm{mg} / \mathrm{l}$ in southern Finland and $0.1-0.3 \mathrm{mg} / 1$ in northern Finland (Järvinen 1986, Ruoho-Airola et al. 1998). Precipitationweighted annual mean values for ammonium are $0.2-0.4 \mathrm{mg} / \mathrm{l}$ in the southern and $0.05-0.20 \mathrm{mg} / 1$ in the northern part of the country (Ruoho-Airola et al. 1998). Mean concentrations of $\mathrm{NH}_{4}$ and $\mathrm{NO}_{3}$ in snow samples collected from the Vaasa region were $0.2-0.3$ and $1.6-1.8 \mathrm{mg} / \mathrm{l}$, respectively (Soveri \& Peltonen 1996). The highest mean nitrate content $(2.5 \mathrm{mg} / \mathrm{l})$ was recorded in the southern part of the area. The deposition level of $\mathrm{NO}_{3}$ has been reported to be relatively stable during the 18 year observation period (1976-1993). The contents of $\mathrm{NH}_{4}$ and $\mathrm{NO}_{3}$ in most of the aquifers included into the present study are less than 0.3 and $2.0 \mathrm{mg} / 1$, respectively. Considering the median values of nitrogen compounds (Table 1), the similarity between the chemical composition of rainwater/snow and bedrock groundwater occurring under natural conditions is evident.

\section{CORRELATIONS BETWEEN CHEMICAL PARAMETERS}

Pearson correlation matrix was computed for the geochemical parameters determined in this study (Table 2). The matrix is presented for the whole data. The data sets of separate wells are insufficient (3-10 series of analyses) to calculate significant correlation coefficients. Therefore, the r-values express some general geochemical relationships within the entire studied region.

Table 2. Correlation matrix for the hydrochemical parameters.

\begin{tabular}{|c|c|c|c|c|c|c|c|c|c|}
\hline & $\mathrm{pH}$ & EC & $\mathrm{O}_{2}$ & $\mathrm{KMnO}_{4}$ & $\mathrm{NH}_{4}$ & $\mathrm{NO}_{2}$ & $\mathrm{NO}_{3}$ & $\mathrm{Fe}$ & $\mathrm{Mn}$ \\
\hline $\mathrm{EC}$ & 0.49 & & & & & & & & \\
\hline $\mathrm{O}_{2}$ & 0.13 & -0.63 & & & & & & & \\
\hline $\mathrm{KMnO}_{4}$ & -0.17 & -0.01 & 0.88 & & & & & & \\
\hline $\mathrm{NH}_{4}$ & 0.01 & 0.24 & -0.67 & 0.20 & & & & & \\
\hline $\mathrm{NO}_{2}$ & 0.09 & 0.15 & -0.35 & -0.07 & 0.06 & & & & \\
\hline $\mathrm{NO}_{3}$ & -0.25 & 0.13 & 0.08 & 0.18 & 0.18 & 0.12 & & & \\
\hline $\mathrm{Fe}$ & 0.05 & -0.15 & -0.47 & 0.10 & 0.43 & 0.10 & -0.16 & & \\
\hline $\mathrm{Mn}$ & 0.05 & 0.31 & -0.61 & 0.04 & 0.57 & 0.03 & 0.07 & 0.45 & \\
\hline $\mathrm{Cl}$ & 0.54 & 0.85 & -0.59 & -0.10 & 0.08 & -0.04 & 0.06 & -0.20 & 0.19 \\
\hline
\end{tabular}

$\mathrm{EC}=$ electrical conductivity.

$\mathrm{KMnO}_{4}=\mathrm{KMnO}_{4}$ consumption. 

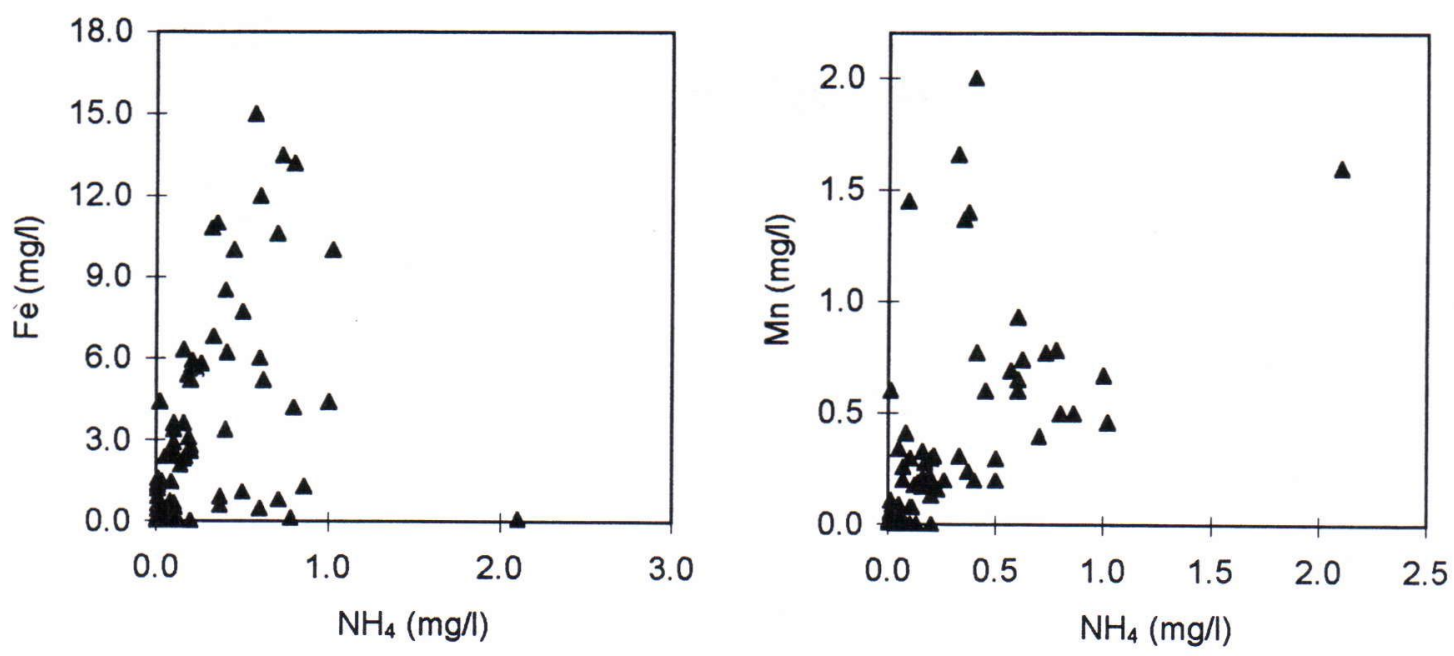

Fig. 4. The concentrations of $\mathrm{Fe}$ and Mn plotted against ammonium concentration.

Under reducing conditions deficient in oxygen, nitrogen compounds occur in part in the low oxidization states, as nitrite and ammonium, whereas under oxidizing conditions they occur mainly as nitrate. When water becomes anoxic and the environment gets reduced, $\mathrm{Fe}$ and $\mathrm{Mn}$ dissolve in the water. The observed iron concentrations in the Vaasa region range from nil to a maximum of 15.0 $\mathrm{mg} / \mathrm{l}$. The corresponding figures for manganese are nil and $2.0 \mathrm{mg} / \mathrm{l}$, respectively. In $75 \%$ of the monitored aquifers the iron content has been higher than the limit value $(0.2 \mathrm{mg} / \mathrm{l})$, and in some wells (Röyskölä, Harrström, Peräseinäjoki, Rintakangas, Kosola, Lavo) the $\mathrm{Fe}$ concentrations ranging between 3.0 to $7.0 \mathrm{mg} / \mathrm{l}$ are quite common. As to the extremely high iron contents, the conditions prevailing in the aquifer must be highly reduced; consequently, some of the dissolved total nitrogen occurs as ammonium and there are very small amounts of nitrate (Fig. 2, columns 1).

The formation of $\mathrm{NH}_{4}$-humus complexes explains the simultaneous occurrence of ammonium and iron in groundwater (Hem 1970). This is indicated by positive correlation between the ammonium and the iron concentrations $(r=0.43)$ as well as between the ammonium and the manganese contents $(r=0.57)$ in bedrock groundwater (Fig. 4). However, the correlation between $\mathrm{NH}_{4}$ and $\mathrm{KMnO}_{4}$-consumption value is not significant $(\mathrm{r}=$
$0.20)$. The occurrence of iron in natural waters is generally regarded to be associated with the concomitant occurrence of manganese. In the Vaasa area there exists a moderate positive correlation between iron and manganese in groundwater $(r=$ $0.45)$.

The most sensitive inorganic indicators of human activities in groundwater are $\mathrm{NO}_{3}$ and $\mathrm{Cl}(\mathrm{La}-$ hermo 1988, Lahermo et al. 1990, Korkka-Niemi et al. 1993). There exists no correlation between these compounds in the study area, thus the abundance of chlorides in the bedrock water cannot be attributed to any noteworthy extent to pollution. Only in Norrby and Petalax the increase of nitrogen compounds was followed by the simultaneous increase of $\mathrm{Cl}$ concentration in groundwater. Electrical conductivity correlates strongly with the concentration of chlorides $(r=0.85)$ (Fig. 5). Relict salts, originating from the postglacial Litorina Sea which inundated large coastal areas 5000 to 7000 years ago (Fig. 1), are the probable sources of high $\mathrm{Cl}$ concentrations in coastal aquifers.

Nitrate has a slight negative correlation with the $\mathrm{pH}$ value $(\mathrm{r}=-0.25)$. Approximately the same result $(\mathrm{r}=-0.28)$ was derived from the hydrogeochemical study of Finnish groundwater (Lahermo et al. 1990). The application of ammonium fertilizers and/or acid atmospheric deposition is reflected in some decline in the $\mathrm{pH}$ values. Ammo- 


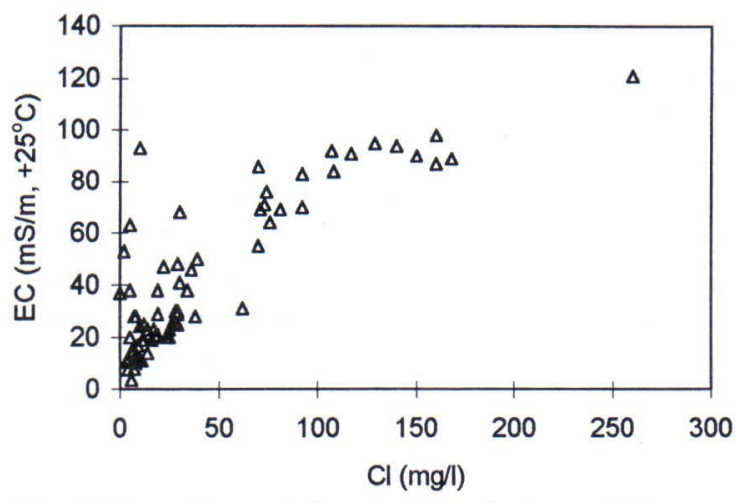

Fig. 5. The values of electrical conductivity (EC) as a function of the chloride concentration.

nium displaces exchangeable calcium from soils. Some of this $\mathrm{Ca}$ will be lost in infiltrating water, and the exchangeable ammonium is nitrified releasing $\mathrm{H}^{+}$. The nitrate formed is either lost by leaching or is taken up by the crops (Mather 1993). The other reasons for the slight declining $\mathrm{pH}$ level of groundwater may be the washing of acid humus-rich soil water from surrounding peatlands into the aquifers and the chemical weathering of primary sulfides in the soil and bedrock.

\section{CONCLUSIONS}

The groundwater quality in the terms of nitrogen compounds is good in the studied bedrock aquifers. Maximum permissible concentrations of $\mathrm{NH}_{4}$ and $\mathrm{NO}_{3}$ in water set by Finnish and international standards have been exceeded only in few samples. Decreasing trends of $\mathrm{NH}_{4}$ and $\mathrm{NO}_{3}$ abundances in bedrock wells can be observed during the last 30 years. A clear effect of anthropogenic sources on the groundwater chemistry is not evident, although it may be recognized in the Norrby and Stranden water plants as a point-source pollution. The atmospheric deposition of nitrogen species and the decomposition of organic matter in humus-rich soil are assumed to be the main sources of nitrogen compounds in groundwater.

The Vaasa area is characterized by reducing conditions prevailing in clay-covered bedrock aquifers. The oxygen deficiency is reflected in the elevated iron and manganese contents in groundwater. Consequently, the amount of nitrate in groundwater is low compared with bedrock groundwater of Finland as a whole.

Chloride abundances close to $100 \mathrm{mg} / \mathrm{l}$ (in 6 of 23 monitored wells) increase electrical conductivity of groundwater. The elevated $\mathrm{Cl}$ concentration cannot be attributed to intrusion of sea water into aquifers. The distances from the recent coastline to the Isokyrö and Ruto water supply plants, where the highest $\mathrm{Cl}$ contents were recorded, are 20 and $12 \mathrm{~km}$, respectively. Leaching of fossil marine salts or relict sea water preserved in fractures of bedrock are plausible sources of the salinity of groundwater.

ACKNOWLEDGEMENTS. Author is grateful to the staff of West Finland Regional Environment Center for the permission to use their monitoring data. I express my thanks to Dr. Pertti Lahermo and Dr. Esa Rönkä for the critical review of this paper and to Mr. Stephen Frindt for checking the English language of the text.

\section{REFERENCES}

Anonymous 1994. Soveltamisopas. Sosiaali- ja terveysministeriön päätös talousveden laatuvaatimuksista ja valvontatutkimuksista. Vesi- ja viemärilaitosyhdistys. 20 p.

Banks, D., Rohr-Torp, E. \& Skarphagen, H. 1992. An integrated study of a Precambrian granite aquifer, Hvaler, Southeastern Norway. Norges geologiske unders $\varnothing$ kelse, Bulletin 422, 47-66.

Hem, J.D. 1970. Study and interpretation of the chemical characteristics of natural water. Geological Survey Water-Supply Paper 1473, Washington. 363 p.

Hrkal, Z. 1992. Acidification of groundwater in the Bohemian Massif. Norges geologiske unders $\varnothing$ kelse, Bulletin 422, 97-102.

Hyyppä, J. 1984. Pohjaveden kemiallinen koostumus Suomen kallioperässä. Summary: Chemical composition of ground water in the bedrock of Finland. Nuclear Waste Commission of Finnish Power Companies, Raportti YJT-84-10. 69 p.

Jacks, G. 1973. Chemistry of some groundwater in silicate rocks. Department of Hand Improvement and Drainage, Royal Institute of Technology, Stockholm. 73 p.

Järvinen, O. 1986. Laskeuman laatu Suomessa 1971-1982. Summary: The deposition quality in Finland 1971-1982. National Board of Waters, Raportti 408. 142 p. 
Knutsson, G. 1994. Acidification effects on groundwater - prognosis of the risks for the future. In: Soveri, J. \& Suokko, T. (eds.) Future Groundwater Resources at Risk. IAHS Publication 222, 7-17.

Korkka-Niemi, K., Sipilä, A., Hatva, T., Hiisvirta, T., Lahti, K. \& Alfthan, G. 1993. Valtakunnallinen kaivovesitutkimus, Talousveden laatu ja siihen vaikuttavat tekijät Abstract: Nationwide rural well water survey, The quality of household water and the factors influencing it. Sosiaali- ja terveysministeriön selvityksiä 2/93, Vesi- ja ympäristöhallinnon julkaisuja A 146. 228 p.

Laakso, M. 1966. Kalliokaivojen veden laatu ja antoisuus. Maataloushallituksen insinööriosasto, Maa- ja vesiteknillinen tutkimustoimisto. Tied. 2.86 p.

Lahermo, P. 1988. Atmospheric, geological, marine and anthropogenic effects on groundwater quality in Finland. Water Science and Technology 20, 33-39.

Lahermo, P. 1991. Aspects of acidification of groundwaters in Finland. In: Pulkkinen, E. (ed.) Environmental Geochemistry in Northern Europe - Proceedings of the first symposium on environmental geochemistry in northern Europe, Rovaniemi 17-19 October. Geological Survey of Finland, Special Paper 9, 131-139.

Lahermo, P. 1994. The acidification of shallow groundwater and stream waters and its environmental controls in Finland. In: Kovar, K. \& Soveri, J. (eds.) Groundwater Quality Management, IAHS Publication 220, 29-38.

Lahermo, P., Ilmasti, M., Juntunen, R. \& Taka, M. 1990. The geochemical Atlas of Finland: The hydrogeochemical mapping of Finnish groundwater. Espoo: Geological Survey of Finland. 66 p.

Mather, J.D. 1993. Pollution of shallow hard rock system - an overview. In: Banks, S. \& Banks, D. (eds.) Hydrogeology of Hard Rocks. I.A.H. Memories, Vol. XXIV, Part 2, 797-808.

Niini, H. 1987. Bedrock fractures affecting land uplift in Finland. In: Perttunen, M. (ed.) Fennoscandian land uplift. Geological Survey of Finland, Special Paper 2, 5154.
Olofsson, B. 1994. Flow of groundwater from soil to crystalline bedrock. Applied Hydrogeology 3, 71-83.

Pirhonen, V. 1990. Porosity and focused dissolution of granitic rocks in two study areas in southern Finland. Aspects of methodology. Espoo: Technical Research Centre of Finland, Publications 69. 109 p.

Ruoho-Airola, T., Syri, S. \& Nordlund, G. 1998. Acid deposition trends at the Finnish Integrated Monitoring catchments in relation to emission reductions. Boreal Environment Research 3, 205-219.

Rönkä, E. 1983. Drilled wells and ground water in the Precambrian crystalline bedrock of Finland. National Board of Waters, Finland. Publications of the Water Research Institute $52.57 \mathrm{p}$.

Salmi, M. 1985. Studies of groundwater flow conditions in crystalline bedrock in southern Finland and its significance to the final disposal of nuclear waste. Geological Survey of Finland, Nuclear Waste Disposal Research Report 42.98 p.

Simonen, A. 1980. The Precambrian of Finland. Geological Survey of Finland, Bulletin 304. 58 p.

Soveri, J. 1992. Acidifying effects on groundwater. In: Schneider, T. (ed.) Acidification Research, Evaluation and Policy Applications. Amsterdam: Elsevier Science Publishers. 135-143.

Soveri, J. \& Peltonen, K. 1996. Lumen ainepitoisuudet ja talvikauden laskeuma Suomessa vuosina 1976-1993. Suomen ympäristökeskus. Suomen Ympäristö 6. 40 p.

Stevenson, F.J. 1962. Chemical state of the nitrogen in rocks. Geochimica et Cosmochimica Acta 26, 797-809.

Swedberg, S. 1989. Groundwater acidification in southwestern Sweden; long-term changes in groundwater chemistry. Geologiska Institutionen, Chalmers Tekniska Högskola och Göteborgs Universitet, Publ. A 67. 27 p.

Talvitie, J. 1979. Seismo-tectonics in Finland. Geologiska Föreningens i Stockholm Förhandlingar 100, 247-253.

Taylor, S.R. 1964. Abundance of chemical elements in the continental crust: a new table. Geochimica et Cosmochimica Acta 28, 1273-1285. 